\title{
Multiethnolect - Part of Urban Stylistic Practices
}

PIA QUIST

This article deals with 'multiethnolect' as a part of urban stylistic practices among Copenhagen high school students. An approach to multiethnolect as a practice is compared to the more traditional approaches which in the article are called the variety approach and the inter-language approach. The first Danish study of multiethnolect in Copenhagen, Quist 2000, was carried out within the perspective of the variety approach, i.e. the colloquial speech of young people in multiethnic areas of Copenhagen was described as a variety with systematic divergences vis-à-vis traditional standard Copenhagen. In another study, Quist 2005, the use of multiethnolect was investigated in a local community of practice. Ethnographic observations, questionnaires and tape recordings were analyzed with the purpose of finding out who the users of multiethnolect are and how multiethnolect forms part of the local stylistic practices. The article concludes that multiethnolect is an integrated part of the Copenhagen speech community and cannot be fully understood as a practice if it is looked at in isolation from the sociolinguistic and dialectological space in which it has developed and in which it is being employed. 